\title{
Effects of L-Carnitine on Liver Enzymes in Rats Fed Cholesterol Rich Diet
}

\author{
Ercan Keskin ${ }^{1}$, Deniz Uluisik ${ }^{1,}$, , Mehmet Altin ${ }^{2}$ \\ ${ }^{1}$ Department of Physiology, Faculty of Veterinary Medicine, University of Selcuk, Konya, Turkey \\ ${ }^{2}$ School of Physical Education and Sports, University of Selcuk, Konya, Turkey \\ Email address: \\ ekeskin@selcuk.edu.tr (E. Keskin), denizfedai@selcuk.edu.tr(D. Uluisik), mealtin@selcuk.edu.tr (M. Altin)
}

\section{To cite this article:}

Ercan Keskin, Deniz Uluisik, Mehmet Altin. Effects of L-Carnitine on Liver Enzymes in Rats Fed Cholesterol Rich Diet. Animal and Veterinary Sciences. Vol. 3, No. 4, 2015, pp. 117-119. doi: 10.11648/j.avs.20150304.14

\begin{abstract}
L-carnitine is essential for energy production and fatty acid metabolism. This study was designed to evaluate effects of L-carnitine on liver enzymes in rats fed cholesterol rich diet. Thirty two healthy male Wistar Albino rats were divided to four groups as Control (K), Cholesterol (C), L-carnitine (L) and L-carnitine+cholesterol (LC). All rats were kept in individual cages during the experiment for 40 days. $\mathrm{K}$ group was fed standard rat pellets ad libitum, $\mathrm{C}$ group was fed standard rat pellets containing $7.5 \%$ cholesterol powder, L group was fed standard rat pellets and water containing $75 \mathrm{mg} / 1 \mathrm{~L}-\mathrm{carnitine}$ and LC group was fed standard rat pellets containing 7.5\% cholesterol and water containing $75 \mathrm{mg} / 1 \mathrm{~L}$-carnitine. At the end of the study, blood samples were taken from all animals in order to determine aspartase transaminase (AST), alanine transaminase (ALT), alkaline phosphatase (ALP), and gamma-glutamyltransferase (GGT)levels. AST, ALT, ALP, and GGT levels significantly increased in $\mathrm{C}$ group compared to $\mathrm{K}$ group $(\mathrm{p}<0.05)$. In LC group, AST, ALT, ALP levels significantly decreased compared with the $\mathrm{C}$ group $(\mathrm{p}<0.05)$. Although GGT level in LC group was decreased, the change was not different from $\mathrm{C}$ group. These results indicate that L-carnitine may prevent liver damage caused by high cholesterol diet in rats.
\end{abstract}

Keywords: L-carnitine, Cholesterol, Liver Enzymes, Rat

\section{Introduction}

Hyperlipidemia is one of the risk factors for fatty infiltration of the liver. This condition can cause other disorders such as cirrhosis and liver failure [1, 2, 3, 4]. Some studies report strict association between liver disease and the prevalence of metabolic disorders (dyslipemia, insulin resistance and hyperglycemia) [5]. On the other hand, several evidences suggest that hyperlipidemia may not cause liver injury, but may be effective in the severity of tissue damage [6]. Although lipid accumulation in the form of triglycerides in the hepatocytes does not primarily impair liver functions, this accumulation significantly increases the susceptibility of the liver to the harmful effects of cytokines and oxidative products $[7,8,9]$.

L-carnitine ( $\gamma$-three methyl amino- $\beta$-hydroxyl fatty acid) is an essential cofactor in mitochondrial respiration playing an important role in the transfer of long-chain fatty acids from cytosol to mitochondria. First, carnitine and acyl-CoA form acylcarnitine in outer surface of the mitochondrium membrane. Thus, acyl groups could be transferred from cytosolic coenzyme A to the inner surface by exchange with free carnitine using an antiport mechanism. The acyl groups are then transferred from carnitine to coenzyme A within the mitochondrium [10]. Carnitine is associated with buffering of excess acyl-Co A. Also, L-carnitine has a protective effect on lipid peroxidation by lowering the formation of hydrogen peroxide $[11,12,13]$.

One of the mechanisms of beneficial effects of L-carnitine on liver toxicity is the ability to stabilize cell membrane fluidity via regulation of sphingomyeline levels [14]. Lcarnitine has protective properties against the drug induced mitochondrial damage [15]. L-carnitine can be used safely at therapeutic dosages even with long term administration without significant side effects. The most known adverse reactions are agitation, nausea and vomiting $[16,17,18]$.

The main objective of this study was to investigate liver response to L-carnitine supplementation by evaluating the liver enzymes.

\section{Materials and Methods}

Thirty two healthy male Wistar Albino rats were equally 
divided into four groups as Control (K), Cholesterol (C), Lcarnitine (L) and L-carnitine+cholesterol (LC). All rats were kept in individual cages during the experiment for 40 days. $\mathrm{K}$ group was fed standard rat pellets ad libitum (Purina ${ }^{\circledR}$, Optima Besin Maddeleri San. ve Tic. A.Ş., Balıkesir, Turkey), $\mathrm{C}$ group was fed standard rat pellets containing $7.5 \%$ cholesterol powder (Sigma-Aldrich, Steinheim, Germany), L group was fed standard rat pellets and water containing 75 $\mathrm{mg} / \mathrm{l}$ L-carnitine (Solgar Vitamin and Herb, Leonia, NJ) and LC group was fed standard rat pellets containing 7.5\% cholesterol and water containing $75 \mathrm{mg} / \mathrm{l} \mathrm{L}$-carnitine. At the end of the study, blood samples were taken from all animals. In these blood samples, aspartase transaminase (AST), alanine transaminase (ALT), alkaline phosphatase (ALP), and gamma-glutamyltransferase (GGT) were determined in an ILAB 300 autoanalyzer using ILAB300 kits. The data were analyzed using one-way ANOVA (SPSS 17). Differences among the groups were determined by Duncan's multiple range test. Differences were considered significant at $\mathrm{p}<0.05$.

\section{Results}

AST, ALT, ALP and GGT levels from all groups are summarized in Table 1. In present study, AST, ALT, ALP, and GGT levels were significantly increased in $C$ group animals compared to $\mathrm{K}$ group rats (Table $1, \mathrm{p}<0.05$ ). In the LC group, AST, ALT, and ALP levels were significantly decreased compared with the $\mathrm{C}$ group (Table $1, \mathrm{p}<0.05$ ), but still higher than in the controls (K). Although the GGT level in the LC group was also decreased, this change was not significantly different from the $\mathrm{C}$ group. L-carnitine administration alone didn't change any parameters compared to K group's levels.

Table 1. The AST, ALT, ALP and GGT levels in the blood from animals of all four test groups (Mean $\pm S E$ ).

\begin{tabular}{lllll}
\hline $\begin{array}{l}\text { Group } \\
(\mathbf{n}=\mathbf{8})\end{array}$ & AST U/L & ALT U/L & ALP U/L & GGT U/L \\
\hline K & $70,63 \pm 2,89^{\mathrm{bc}}$ & $37,13 \pm 2,29^{\mathrm{b}}$ & $122,75 \pm 7,90^{\mathrm{c}}$ & $6,33 \pm 0,44^{\mathrm{b}}$ \\
$\mathrm{C}$ & $88,38 \pm 4,01^{\mathrm{a}}$ & $46,88 \pm 1,71^{\mathrm{a}}$ & $198,25 \pm 6,98^{\mathrm{a}}$ & $8,28 \pm 0,50^{\mathrm{a}}$ \\
$\mathrm{L}$ & $65,88 \pm 3,88^{\mathrm{c}}$ & $36,50 \pm 2,86^{\mathrm{b}}$ & $115,50 \pm 7,03^{\mathrm{c}}$ & $6,23 \pm 0,64^{\mathrm{b}}$ \\
LC & $77,25 \pm 2,70^{\mathrm{b}}$ & $39,75 \pm 2,44^{\mathrm{b}}$ & $152,88 \pm 9,13^{\mathrm{b}}$ & $7,16 \pm 0,56^{\mathrm{ab}}$ \\
\hline
\end{tabular}

The difference between mean values with different superscripts in the same column is significant at the $\mathrm{p}<0.05$ level.

\section{Discussion}

Changes in the activities of AST, ALT, ALP, and GGT are liver specific and have been considered as a tool to study varying cell viability and cell membrane permeability and are the well-known indicators of liver cell and tissue damage [19, 20].

Hypercholesterolemia has been considered a risk factor for hepatic injury [21, 22, 23]. Hepatic damage induced by cholesterol-rich diet has been noted [24, 25, 26]. Previous studies on rats and rabbits have demonstrated intense lipid accumulation in hepatic areas after feeding with high cholesterol diet $[24,27,28]$. Liver fibrosis is a primary indicator of hepatic lipid accumulation [24]. In our study, the significant increases in AST, ALT, ALP, and GGT levels (Table $1, \mathrm{p}<0.05$ ) following high cholesterol diet may also be a result of hepatic damage. Previous studies reported that high cholesterol diet resulted in elevation of liver enzyme levels in agreement with our results [25, 29].

In this study, L-carnitine administration to the high cholesterol diet of the rats resulted in a significant decrease in liver enzymes levels compared to the $\mathrm{C}$ group (Table 1, $\mathrm{p}<0.05$ ). Our results support that L-carnitine supplementation prevents hepatic injury and enzyme leakage from hepatocytes $[13,30]$. It has been reported that L-carnitine reduced lipid accumulation in liver [31]. Also, L-carnitine reduces obesity caused by high fat diet and exogenously added carnitine inhibited the increase in triglyceride and total lipid levels [32]. The main function of L-carnitine is facilitation of lipid oxidation by transporting long chain fatty acids into the mitochondria where they undergo $\beta$-oxidation [33]. Therefore, most of dietary lipids can be used as an energy source with carnitine in body [34]. In addition, L-carnitine was shown to have antioxidant properties with protective effects against free radical damage [35, 36, 37]. Thus, the significant decreases (Table $1, \mathrm{p}<0.05$ ) in hepatic enzyme activities with the L-carnitine may be related to lipid lowering effects of Lcarnitine and its antioxidant properties also in our study.

\section{Conclusion}

The results from the present investigation indicate that treatment with L-carnitine protects the liver from damage of high cholesterol diet in rats.

\section{References}

[1] Alpers, D. H., Sabesin, S. M. and White, H. M. (1993). Fatty liver: biochemical and clinical aspects. In Disease of the Liver, 7th ed., L Schiff and ER Schiff (eds). Philadelphia: JB Lippincott, 825-855.

[2] Ludwig, J., Viggiano, T. R., McGill, D. B. and Ott, B. J. (1980). Nonalcoholic steatohepatitis. Mayo clinical experiences with a hitherto unnamed disease. Mayo Clin. Proc., 55: 434-438.

[3] Alder, M. and Schaffner, F. (1979). Fatty liver hepatitis and cirrhosis in obese patients. Am. J. Med., 67: 811-816.

[4] Assy, N., Kaita, K., Mymin, D., Levy, C., Rosser, B. and Minuk, G. (2000). Fatty Infiltration of Liver in Hyperlipidemic Patients. Dig. Dis. Sci., 45(10): 1929-1934.

[5] Must, A., Spadano, J., Coakley, E. H., Field, A. E., Colditz, G. and Dietz, W. H. (1999). The disease burden associated with overweight and obesity. JAMA., 282: 1523-1539.

[6] Jou, J., Choi, S. S. and Diehl, A. M. (2008). Mechanisms of disease progression in nonalcoholic fatty liver disease. Semin. Liver Dis., 28: 370-379.

[7] Farrell, G. C. and Larter, C. Z. (2006). Nonalcoholic fatty liver disease: from steatosis to cirrhosis. Hepatol., 43: 99-112. 
[8] McIntyre, M., Benhamou, J. P., Bircher, J., Rizzeto, M. and Rodes, J. (1999) Oxford Textbook of Clinical Hepatology. Oxford, UK: Oxford University Press.

[9] Ferre, N., Martinez-Clemente, M., Lopez-Parra, M., Gonzalez-Periz, A., Horrillo, R., Planaguma, A., Camps, J., Joven, J., Tres, A., Guardiola, F., Bataller, R., Arroyo, V. and Claria, J. (2009). Increased susceptibility to exacerbated liver injury in hypercholesterolemic ApoE-deficient mice: potential involvement of oxysterols. Am. J. Physiol. Gastrointest. Liver Physiol., 296: 553-562.

[10] Kelly, G. S. L. (1998). Therapeutic applications of a conditionally essential amino acid. Altern. Med. Rev., 3: 345360 .

[11] Brass, E. M. (2000). Supplemental carnitine and exercise. Am. J. Clin. Nutr., 72: 618-623.

[12] Rani, P. J. and Panneerselvam, C. (2002). Effect of L-carnitine on brain lipid peroxidation and antioxidant enzymes in old rats. J. Gerontol. A Biol. Sci. Med. Sci., 57: 134-137.

[13] Yapar, K., Kart, A., Karapehlivan, M., Atakisi, O., Tunca, R., Erginsoy, S. and Citil, M. (2007). Hepatoprotective effect of L-carnitine against acute acetaminophen toxicity in mice. Exp. Toxicol. Pathol., 59: 121-128.

[14] Capecchi, P. L., Laghi Pasini, F., Quartarolo, E. and Di Perri, T. (1997). Carnitines increase plasma levels of adenosine and ATP in humans. Vasc. Med., 2: 77-81.

[15] Nikula, P., Ruohola, H., Alhonen-Hongisto, L. and Jänne, J. (1985). Carnitine prevents the early mitochondrial damage induced by methyloglyoxal bis(guanylhydrazone) in L1210 leukemia cells. Biochem. J., 228: 513-516.

[16] Rai, G., Wright, G., Scott, L., Beston, B., Rest, J. and ExtonSmith, A. N. (1990). Double-blind, placebo controlled study of acetyl-L-carnitine in patients with Alzheimer's dementia. Curr. Med. Res. Opin., 11(10): 638-647.

[17] Spagnoli, A., Lucca, U., Menasce, G., Bandera, L., Cizza, G. and Forloni, G. (1991). Long-term acetyl-L-carnitine treatment in Alzheimer's disease. Neurology, 41: 1726-1732.

[18] Hashemi, A., Souzani, A., Meshkani, M., Osia, S., Shahvazian, N., Keshavarzi, S. and Atefi, A. (2011). Efficacy of Lcarnitine on liver function in childrens under chemotherapy with acute lymphoblastic leukemia. Iran. J. Pediatr. Hematol. Oncol., 2(1): 43-47.

[19] Renugadevi, J. and Prabu, S. M. (2010). Cadmium-induced hepatotoxicity in rats and the protective effect of naringenin. Exp. Toxicol. Pathol., 62(2): 171-181.

[20] El-khishin, I. A. and Amer, M. G. (2010). Possible Protective Role of L-carnitine on Diclofenac Induced Hepatotoxicity in Adult Male Albino Rats (Histological, Immunohistochemical and Biochemical Study). Egypt. J. Histol., 33(2): 341-352.

[21] Castelli, W. P., Garrison, R. J., Wilson, P. W. F., Abbott, R. D., Kalousdian, S. and Kannel, W. B. (1986). Incidence of coronary heart disease and lipoprotein cholesterol levels. The Framingham Study. JAMA, 256: 2835-2838.

[22] Wudel, L. J., Wright, J. K., Debelak, J. P., Allos, T. M., Shyr, Y and Chapman, W. C. (2002). Prevention of Gallstone Formation in Morbidly Obese Patients Undergoing Rapid
Weight Loss: Results of a Randomized Controlled Pilot Study. J. Surg. Res., 102(1): 50-56.Ronnemaa, T., Pelliniemi, T. T. and Kulonen, E. (1976). Factors stimulating collagen synthesis from the livers of hypercholesterolemic rats. Atherosclerosis, 26: 311-321.

[24] Buyssens, N., Kockx, M. M., Herman, A. G., Lazou, J., Van den Berg, K., Wisse, E. and Geerts, A. (1996). Centrolobular liver fibrosis in the hypercholesterolemic rabbit. Hepatology, 24(4): 939-946

[25] Nanji, A. A., Rahemtulla, A., Daly, T., Khwaja, S., Miao, L., Zhao, S. and Tahan, S. R. (1997). Cholesterol supplementation prevents necrosis and inflammation but enhances fibrosis in alcoholic liver disease in the rat. Hepatology, 26(1): 90-97.

[26] Wang, J. M., Su, S., Gong, W. and Oppenheim, J. J. (1998). Chemokines, receptors, and their role in cardiovascular pathology. Int. J. Clin. Lab. Res., 28(2): 83-90.

[27] Del Moral, M. L., Esteban, F. J., Torres, M. I., Camacho, M. V., Hernandez, R., Jimenez, A., Aranega, A., Pedrosa, J. A. and Peinado, M. A. (1997). High-fat sunflower and olive oil diets affect serum lipid levels in steatotie rat liver differently. J. Nutr. Sci. Vitaminol., 43: 155-160.

[28] Ramadori, G., Veit, T., Schwögler, S., Dienes, H. P., Knittel, T., Rieder, H. and Meyer zum Büschenfelde, K. H. (1990). Expression of the gene of the $\alpha$-smooth muscle-actin isoform in rat liver and in rat fat-storing (ITO) cells. Virchows. Arch. B Cell Pathol., 59(1): 349-357.

[29] Jeong, W. I., Jeong, D. H., Do, S. H., Kim, Y. K., Park, H. Y., Kwon, O. D., Kim, T. H. and Jeong, K. S. (2005). Mild hepatic fibrosis in cholesterol and sodium cholate diet-fed rats. J. Vet. Med. Sci., 67(3): 235-242.

[30] Mansour, H. H. (2006). Protective role of carnitine ester against radiation-induced oxidative stress in rats. Pharmacol. Res., 54(3): 165-171.

[31] Sachan, D. S., Rhew, T. H. and Ruark, R. A. (1984). Ameliorating effects of carnitine and its precursors on alcohol-induced fatty liver. Am. J. Clin. Nutr., 39: 738-744.

[32] Cha, Y. S., Eun, J. S. and Oh, S. H. (2003). Carnitine Profiles during differentiation and effects of carnitine on differentiation of 3T3-L1 cells. J. Med. Food., 6: 163-167.

[33] Bieber, L. L. (1998). Carnitine. Annu. Rev. Biochem., 57: 261-283.

[34] Cha, Y. S. (2008). Effects of L-carnitine on obesity, diabetes, and as an ergogenic aid. Asia Pac. J. Clin. Nutr., 17(1): 306308 .

[35] Pallor, M. S., Holdal, J. R. and Ferris, T. F. (1984). Oxygen free radicals in ischemi acute renal failure in the rat. J. Clin. Invest., 74: 1156-1164.

[36] Ashraf, V., Franco, G., Syed, I., Zbigniew, B. and Syed, A. (2002). The protective role of L-carnitine against neurotoxicity evoked by drug of abuse, methamphetamine, could be related to mitochondrial dysfunction. Ann. N. Y. Acad. Sci., 965: 225-232.

[37] Kart, A., Yapar, K., Karapehlivan, M. and Citil, M. (2007). The Possible Protective effect of L-carnitine on Tilmicosininduced Cardiotoxicity in Mice. J. Vet. Med. A, 54: 144-146. 